\section{Research without benefit}

The British defence establishment has been warned that its research must be more useful to others.

Is there a chance that the next British Government (which will probably take office four weeks from the date of this issue) will find a way of bringing its spending on defence research and development within the compass of its general economic policy? This question is not as partisan as it may seem, for it is no more pointed now than at any of the other elections since the Second World War. For it has been a constant source of complaint since then that defence research and development has taken the lion's share of all spending on research and development, but that British industry has benefited only in minor ways from what has been spent. At the outset, when the momentum of the wartime research establishments was still huge, it was also possible fairly to complain that too great a proportion of what the services spent on research and development was spent within their own research establishments, but over the years the proportion has declined with the enforced restriction of public spending to the point at which most development and nearly half of research in military fields is spent on contracts with industrial companies. Yet even with this huge shift of resources, British industry seems not to be a conspicuous beneficiary of military spending. Why should things be so different elsewhere, in the United States particularly, but also in countries such as France?

For many of the past several decades, successive governments' critics have been asking that there should be a formal inquiry into this important question, but so far in vain. For most of that time, the Ministry of Defence has taken the view that defence research is too vital to national security to be compromised by merely commercial considerations - and that, anyway, it is secret. The nearest approximation to such an inquiry was that which led in 1962 to the Gibbs-Zuckerman report which was so devoid of tangible examples of what was being done in the name of defence research that it has served principally as grist for academic mills. But the climate is obviously changing. The British Government's own Advisory Council on Applied Research and Development is said to have embarked on studies which touch the defence establishment - but will not say what they are about. And the National Economic Development Office, an institutionalized talking shop in which industry, trades unions and the government (the present government reluctantly) participate, had the wit a year ago to commission a study on defence research in relation to electronics from Sir Ieuan Maddock, once chief scientist at the Department of Industry who would no doubt have risen even higher if only more than ten per cent of the British people had known how to pronounce his first name.

As it has emerged, Maddock's rep.ort makes one telling point that the industrial companies most closely involved with defence research are so dependent on their military customers that they do not care, or dare not risk, to spread their wings into other fields unless into various aspects of civil aerospace or the export of military equipment to countries overseas. But the report points to companies at the other end of the spectrum which operate successfully in civil markets for high technology products but which are kept from competing for defence contracts, or even from becoming subcontractors, by the sheer clubbiness of the present system. The report rehearses the many complaints that have been made against the defence research establishments, usually that they attempt too much with their own resources, and comes to the unfashionable conclusion that if civil benefit were the objective, and because the well-established defence contractors are unlikely ever to contribute to civil manufacturing, the defence research establishments should carry out more research than they do at present in the hope that they might then channel some of the benefits towards companies at present outside the defence establishments. This proposal is briskly rejected in a note from the Ministry of Defence published as an appendix.

As things are, the ministry is probably correct. But its devotion to the causes of putting more of its research out to private industry (and why not universities?) would be more convincing if it had emerged much sooner, when the defence laboratories were allowed to employ far too great a share of the country's skilled manpower.

So what is the best way of exploiting defence research? The simplest answer is probably "none of the above". For Sir Ieuan's report in passing is a sombre reminder of how a shrinking national product has made minuscule what even the defence ministry, the richest customer for research in Britain, now spends. The cost last financial year of the research supporting the British services was merely $£ 300$ million, less than the annual expenditure on research and development of many Japanese manufacturers of consumer products. And although the Ministry of Defence spent five times as much on the development of weapons and other gadgets, these days even that would not see a modest development of an undersized supersonic aircraft such as Concorde to completion. Is it that while the British have wasted nearly four decades on how to make civil use of defence research, the goose that used to lay the golden eggs has become a silver gosling?

\section{Records in thin air \\ The Hitler non-diaries should remind historians that their scholarship is not self-sufficient.}

THE fiasco of the supposed rediscovery of Adolf Hitler's diaries is primarily an embarrassment for the newspaper groups that have enjoyed the sense of having scooped their rivals only for a few short weeks - Stern in West Germany and the Sunday Times in Britain. For they must now expect that their readers, given such a spectacular display of gullibility, will ask similarly awkward questions about the rest of what they print. Much the same is true of the academic historians who have been caught up in this tangled tale as "verifiers" of the supposed diaries, most especially Lord Dacre (previously the Oxford historian Hugh TrevorRoper) who spent four hours with the forged documents in the vault of a Swiss bank and publicly, if only briefly, pronounced them to be "authentic". That the newspapers concerned may have been misled by the ironical dictum that too many good stories are lost by too much checking is understandable if inexcusable. That historians should similarly have been led astray is mystifying.

The proofs of forgery adduced last week by the West German Government are not, as it happens, unfamiliar. Diaries supposedly written by Mussolini were quickly shown to have been written on paper manufactured only after his death. Now there are several technical means by which forensic scientists can tell something of the provenance of writing materials. Mussolini's diaries were discredited by a proof that the chemical and fibre composition of the paper was inconsistent with plausible origins. Since then, X-ray analysis of clay used as a smoothing agent in the manufacture of paper has in some cases proved decisive, principally because the trace constituents of clays vary from one region to another. Similarly, the chromatographic analysis of inks has uncovered other fakes, while even pollen analysis has been used to show that forged documents are false by demonstrating that pollen grains embedded in the ink do not correspond with the season at which the documents are supposed to have been written.

While these techniques are by no means simple, the fact of their existence is familiar and their use is widely practised. Moreover, they are techniques that would have splendidly suited Stern's purpose in that it would have been possible to ask whether samples of supposedly pre-war paper were plausibly such without disclosing what was supposed to have been written on it. Putting an historian, however distinguished, in a bank vault with the papers for a few hours is no substitute for objective tests of authenticity, even though it now emerges that many of the entries in the supposed diaries were simply copied from a book published twenty years ago. The next time (and there will be one) that newspapers and historians are required to decide whether documents are forgeries, they should in their own interests give science a chance. 